\title{
Origin and redox conditions of Rosário-6 alkaline occurrence, southern Brazil: implications for mantle conditions during Gondwana breakup
}

CARNIEL, L.C. ${ }^{1 *}$, CONCEIÇÃO, R.V. ${ }^{1}$, KLEMME, S ${ }^{2}$ BERNDT, J. ${ }^{2}$, JALOWITZKI, T.R. ${ }^{3}$

${ }^{1}$ LAGEPE, Universidade Federal do Rio Grande do Sul, Porto Alegre, Brazil (*correspondence:

larissa.colombo@ufrgs.br)

${ }^{2}$ Institut für Mineralogie, Westfälische Wilhelms-Universität Münster, Germany

${ }^{3}$ Instituto de Geociências, Universidade de Brasília, Brazil

The Rosário- 6 alkaline hypabyssal occurrence is situated in the south-eastern edge of the Parana Basin, in the South of Brazil, and erupted concomitant or just after the volcanism of the Paraná-Etendeka Large Igneous Province (LIP). Following the most recent published nomenclature, Rosário-6 occurrence is classified as a kimberlite from a deep mantle source with a distinctive inequigranular texture resulting from the presence of macrocrysts set in a finer-grained matrix. Trace element compositions of olivine, monticellite, spinel, phlogopite, $\mathrm{CaTiO}_{3}$-perovskite and apatite show an enrichment of $\mathrm{Nb}, \mathrm{Ce}, \mathrm{Ta}$ and $\mathrm{U}$, which suggests that Rosário- 6 source was enriched by recycled oceanic crust that caused peridotite fertilization by melts derived from former basaltic crust and subducted carbonates. The positive anomalies of $\mathrm{Rb}, \mathrm{Ba}$ and $\mathrm{Sr}$, the enrichment in LREE, and the negative anomalies of HREE in the Rosário- 6 minerals, are indicative of a metasomatism process in the mantle source that could be caused by fluids from recycled oceanic crust. Crystallization temperature, pressure and oxygen fugacity $\left(f \mathrm{O}_{2}\right)$ conditions of Rosário-6 mantle source are estimated using different methods from olivine, monticellite, spinel and $\mathrm{CaTiO}_{3}$-perovskite compositions, in order to determine the potential of Rosário-6 to preserve diamonds. Horizontal tomographic images for different depths from P-wave velocity anomalies provide evidence concerning the thickness of the lithosphere in this region and points to a mantle cooling at depths below to $200 \mathrm{~km}$, possibly resulted of an accumulation of oceanic plate slabs from old subductions, which characterizes the Rosário- 6 mantle source and the mantle conditions of this region during Gondwana breakup. 